\title{
Pawpaw enriched soymilk beverage
}

\author{
I. F. Bolarinwa ${ }^{1 *}$, T. E. Aruna ${ }^{2}$, R. I. Ajetunmobi ${ }^{3}$, J. A. Adejuyitan ${ }^{1}$ and O. W. Alawode ${ }^{1}$ \\ ${ }^{1}$ Department of Food Science, Ladoke Akintola University of Technology, Ogbomoso, Nigeria \\ ${ }^{2}$ Department of Food Science and Technology, Kwara State University, Kwara State, Nigeria \\ ${ }^{3}$ Department of Food Engineering, Ladoke Akintola University of Technology, Ogbomoso, Nigeria
}

Received: 18 November 2020

Revised: 10 January 2021

Accepted: 31 March 2021

DOI: https://doi.org/10.3329/bjsir.v56i1.54317

\begin{abstract}
Effects of enriching soymilk with pawpaw puree at different ratios $(10-40 \%)$ were evaluated for physicochemical properties, vitamin $\mathrm{A}$ and $\mathrm{C}$, mineral contents, and sensory attributes. The results showed increase in total soluble solids $\left(5.5-8.5^{\circ}\right.$ Brix $)$, total titratable acidity $(0.53-0.87 \mathrm{~g} / \mathrm{kg})$ and viscosity $(19.9-26.7 \mathrm{cp})$, but decreased in $\mathrm{pH}(7.4-6.8)$. Vitamin $\mathrm{A}$ and $\mathrm{C}$ contents of the soy-pawpaw beverage increased from $12.4-20.4 \mu \mathrm{g} / 100 \mathrm{ml}$ and $10.9-25.8 \mathrm{mg} / 100 \mathrm{ml}$, respectively. All the macromineral contents of the enriched soymilk beverages increased significantly except for sodium. Enrichment of soymilk with pawpaw puree improved the sensory attributes of the drink in terms of flavour, taste, mouthfeel and overall acceptance, especially at high supplementation level (40\%). Enrichment of soymilk with pawpaw puree resulted in products with better vitamin $\mathrm{A}$ and $\mathrm{C}$ and macro-mineral contents than plain soymilk drink, thus, the soy-pawpaw beverage will complement consumers micro and macro-nutrient intake.
\end{abstract}

Keywords: Soy-pawpaw beverage; Mineral composition; Physicochemical properties; Vitamin A; Vitamin C; Sensory evaluation

\section{Introduction}

Beverages are foods consumed in liquid form, which can either be alcoholic or non-alcoholic. Non-alcoholic beverages play a key role in the dietary pattern of people in developing countries such as Nigeria. Non-alcoholic beverages are regarded as after meal drinks or refreshing drinks, however, most of these beverages are made up of about $90 \%$ water, sugar, flavouring agents and sometimes preservatives. Although most commercially available non-alcoholic beverages in developing countries are less nutritious, some of them such as soymilk, fruit juices etc., are nutritious and of medicinal value (Aka et al., 2008; Nwachukwu et al., 2010).

Soybean (Glycine max) is an excellent source of protein (35-40\%), containing all the essential amino acids, and rich source of calcium, iron, phosphorus and vitamins (Jiang et al., 2000). It is rich in vitamins (riboflavin, thiamine, folic acid), minerals such as magnesium, lecithin, and also contains all essential fatty acids (Mc Watters et al., 1995). Soybeans contain about 3\% lecithins which are helpful for infant brain development.

Soymilk is a watery extract of whole soybeans, rich in water soluble protein, carbohydrate and oil (Adebayo-Tayo et al., 2008). The milk is a white or creamy emulsion which resembles conventional milk in both appearance and consistency (Iwe, 2003; Kolapo and Oladimeji, 2008). In developing countries, soymilk is one of the most common protein rich healthy alternatives to cow milk. Soymilk is affordable and economical when compared to industrially processed cow milk. Soymilk contains $4.6 \%$ protein, $2.3 \%$ fat, $4.3 \%$ carbohydrate, no cholesterol, no lactose, $15 \%$

\footnotetext{
*Corresponding author e-mail: ifbolarinwa@lautech.edu.ng; islamiyat202@yahoo.co.uk
} 
saturated fatty acid, $64 \%$ polyunsaturated fatty acid and $21 \%$ monounsaturated fatty acid (Adeleke and Odelola, 1997). The increasing popularity of soymilk as a beverage worldwide is credited to its health benefits which includes low cholesterol and lactose, its ability to reduce bone loss and menopausal symptoms, prevention and reduction of heart diseases and certain cancers (Iwe, 2003; Kolapo and Oladimeji, 2008; Adebayo -Tayo et al., 2008).

Pawpaw (Carica papaya L.), which belongs to the family Caricacae is a tropical plant with potential medicinal value, and a rich source of vitamin A and C (Bolarinwa et al., 2020a, 2020b). The fruit high nutritional quality makes it an excellent contributor to a balanced diet. Pawpaw is a potential source of natural fruit flavor and contains high levels of potassium, calcium and iron (Bolarinwa et al., 2020a). It is also a very good source of free-radical scavenging vitamin $\mathrm{A}$, due to its several form of beta-carotene (Dimitrovski et al., 2010).

Enrichment of milk-based or cereal-based foods with fruits such as pawpaw, carrot etc., has been reported to improve the nutritional composition and sensory attributes of the enriched foods. According to Njoya et al. (2017) incorporation of pawpaw puree at different levels in yoghurt preparation improved the flavour of plain yoghurt. In another study, enrichment of natural yoghurt with pawpaw was reported to produce acceptable pawpaw flavoured yoghurt with higher nutritional characteristics (Othman et al., 2019). Enrichment of white bread with pawpaw puree was also reported to improve the micronutrient contents and sensory attributes of the bread (Bolarinwa et al., 2020a). Furthermore, fortification of soymilk with carrot powder has been reported to improve the nutritive quality of soymilk (Madukwe and Eme, 2012). It is therefore expected that incorporation of pawpaw puree into soymilk will enhance the quality attributes of the beverage. Hence, the objectives of this study are to determine the physicochemical properties, vitamin $\mathrm{A}$ and $\mathrm{C}$, mineral contents, and sensory attributes of pawpaw enriched soymilk beverage.

\section{Materials and methods}

\section{Materials}

Soybeans and pawpaw fruits were procured from a local market in Ogbomoso, South West, Nigeria. Soy-pawpaw beverage preparation and experimental analyses were done at Ibrahim Owodunmi Food Processing laboratory, and Food Chemistry laboratory, Ladoke Akintola University of Technology, Ogbomoso, Oyo state, Nigeria. All reagents were of analytical grade.

\section{Methods}

\section{Production of pawpaw puree}

Fresh mature ripe pawpaw fruits (Solo sunrise variety) were selected, washed with 5\% hypochlorite solution and rinsed with distilled water. The fruits were peeled with sterile stainless knife, cut into small pieces of between 3-4 mm thick and seeds were removed. Puree was prepared by blending the pawpaw pulp in a blender for $3 \mathrm{~min}$. The puree was filled in airtight screw cap sterilized glass bottles and refrigerated at $5^{\circ} \mathrm{C}$ for few hours prior to further use.

\section{Production of soymilk}

Soybean (Glycine max L.) (1 kg) was sorted and soaked for $12 \mathrm{~h}$ in clean water $(1: 3 \mathrm{w} / \mathrm{v})$ and decanted. The soybean was dehulled and wet milled $(1: 3 \mathrm{w} / \mathrm{v})$ using hammer mill. The slurry was cooked for 10-15 min. The cooked slurry was cooled for $10 \mathrm{~min}$ and sieved, following addition of $200 \mathrm{~g}$ sugar.

\section{Preparation of pawpaw enriched soymilk beverage}

The soymilk was mixed with pawpaw puree at varying proportions: 100:0 (control sample), 90:0, 80:20, 70:30 and 60:40(soy: pawpaw) (Table I). The blends were homogenized, bottled and pasteurized at $75^{\circ} \mathrm{C}$ for $5 \mathrm{~min}$ in a

Table I. Formulation of pawpaw enriched soymilk beverages

\begin{tabular}{lcc}
\hline Sample & Soymilk $(\%)$ & Pawpaw puree $(\%)$ \\
\hline Plain soymilk & 100 & 0 \\
10\%Soy-pawpaw & 90 & 10 \\
$20 \%$ Soy-pawpaw & 80 & 20 \\
$30 \%$ Soy-pawpaw & 70 & 30 \\
$40 \%$ Soy-pawpaw & 60 & 40 \\
\hline
\end{tabular}


thermostatically controlled water bath with agitator, cooled to room temperature $\left(27 \pm 2{ }^{\circ} \mathrm{C}\right)$ and stored in a refrigerator $\left(5^{\circ} \mathrm{C}\right)$ until analysed.

\section{Physicochemical analyses}

$$
p H
$$

The $\mathrm{pH}$ of the beverage was determined using a digital $\mathrm{pH}$ meter (pHs-2F, Harris, England) according to AOAC (2012) method. $50 \mathrm{ml}$ juice was transferred to a beaker and the $\mathrm{pH}$ was determined after the meter was calibrated using standard buffer solutions of $\mathrm{pH} 4.0$ and 7.0. Sufficient time was allowed for equilibration before readings were taken.

\section{Total titratable acidity (TTA)}

$10 \mathrm{ml}$ beverage was pipetted into a conical flask and $25 \mathrm{ml}$ of distilled water was added, following AOAC (2012). 0.1M $\mathrm{NaOH}(200 \mathrm{ml})$ was poured into a burette and was titrated against the sample in the flask using three drops of phenolphthalein as indicator. The solution was titrated until a pink colouration was observed and the corresponding burette reading taken.

\section{Viscosity determination}

The viscosity of the beverage was determined as described by Awolu et al. (2013), using a Rion-visco-tester (model VA-04F). The soy-pawpaw beverage was poured into the viscometer cup, the rotor was suspended into the sample to rotate and the values was determined in decipascal-second unit (cp) at varying temperatures $\left(30,40\right.$ and $\left.50^{\circ} \mathrm{C}\right)$.

\section{Total soluble solids ( ${ }^{\circ}$ Brix)}

A hand-held sugar refractometer was used for the total soluble solids (TSS) determination. The prism of the refractometer was cleaned and a drop of the beverage was placed on the prism and closed. The TSS ( ${ }^{\circ}$ Brix) value was read off the scale of the refractometer when held close to the eye (AOAC, 2012).

\section{Vitamin A determination}

Vitamin A was extracted from the soy-pawpaw beverage with a mixture of acetone and hexane $(4: 6 \mathrm{v} / \mathrm{v})$ by the method of Singh et al. (2015) and Bolarinwa et al. (2020a). Ten grammes $(10 \mathrm{~g})$ of each drink was extracted with a mixture of $20 \mathrm{ml}$ of acetone and $30 \mathrm{ml}$ of hexane $(4 / 6 \mathrm{v} / \mathrm{v})$. The mixture was poured into a separatory funnel and shaken until the content became homogenous. The mixture was allowed to separate in a dark place (inside a cupboard)and the top layer was taken with a pipette. Optical density was measured at $452 \mathrm{~nm}$ for $\beta$-carotene and converted to vitamin $\mathrm{A}$, as follows;

$$
\begin{aligned}
& B-\text { carotene }(\mu g / 100)=\frac{\text { ODx13.9 } \times 10000 \times 100}{\text { Welght of sample } \times 560 \times 1000} \\
& \text { Vitamin } A=B-\text { carotene }(10 / 100) / 0.6
\end{aligned}
$$

where OD = optical density of the solution at $452 \mathrm{~nm}$

\section{Vitamin C determination}

Vitamin C content was determined by the spectrophotometric method using ascorbic acid as a reference compound. About $10 \mathrm{ml}$ of the beverage sample was weighed into $10 \mathrm{ml}$ of water and mixed together. The extract $(200 \mu \mathrm{l})$ was pipetted and mixed with $300 \mu$ of $13.3 \%$ of trichloro-acetic acid (TCA) and $75 \mu \mathrm{l}(0.075 \mathrm{ml})$ of dinitrophenylhydrazyl (DNPH). The mixture was incubated in water bath at $37^{\circ} \mathrm{C}$ for $3 \mathrm{~h}$, and $500 \mu \mathrm{L}$ of $65 \%$ sulphuric acid was added and the absorbance was read at $520 \mathrm{~nm}$ on a spectrophotometer (Okwu and Josiah, 2006).

\section{Mineral content determination}

The macro-mineral content of the pawpaw enriched soymilk beverage was determined following the method described by Nwozo et al. (2017) with slight modification. The moisture in the beverage was evaporated to concentrate the sample and one gram of the sample was digested with nitric acid/perchloric acid mixtures (1:2). The digest was boiled (5 $\mathrm{min})$, cooled and transferred to $50 \mathrm{ml}$ volumetric flask and made up to mark with diluted water. The resulting digest was filtered using Whatman No.1 filter paper, and the filtrate from each sample was used for the specific mineral analysis using Flame Atomic Absorption Spectrophotometer (Buck Scientific Atomic Absorption Emission Spectrophotometer model 205, Nowalk, Connecticut, USA). All determinations were performed in triplicates.

\section{Sensory evaluation}

Sensory evaluation of the five soy-pawpaw beverage samples were carried out using the preference tests. The samples were served to 50 semi-trained panelists comprising of a population of staff and students of Ladoke Akintola University of Technology (LAUTECH) who are regular consumers of soymilk. Sensory test was conducted in compliance with all regulations and according to established 
ethical guidelines at LAUTECH. The purpose of the study was explained to the panelists verbally and through written information in the sensory form. The panelists signed an informed consent form if they were in agreement with the purpose of the study and submitted it to the researcher. Participants were informed that the soymilk beverages are enriched with pawpaw puree. The beverage samples were randomly labelled numerically and served to the panelists. The panelists were requested to evaluate the colour, flavour, taste, mouthfeel, and overall acceptance of the beverages. A 9-point hedonic scale (with 1 and 9 representing dislike extremely and like extremely, respectively) was used to measure the degree of preference for the beverage samples.

\section{Statistical analysis}

All data obtained in the study were subjected to analysis of variance (ANOVA) using Statistical Package for the Social Science (SPSS) version 17.0., and means were separated with the use of Duncan's multiple range test to detect significant differences $(\mathrm{p} \leq 0.05)$ among the beverage samples.

\section{Results and discussion}

Physicochemical properties of the pawpaw enriched soymilk beverage

The physicochemical properties of the soy-pawpaw beverages are presented in Fig. 1. Fortification of soymilk with pawpaw puree resulted in decrease in the $\mathrm{pH}$ of the soy-pawpaw beverages. The $\mathrm{pH}$ of the plain soymilk was higher (7.4) than the $\mathrm{pH}$ of the pawpaw enriched soymilk drink (7.1 - 6.8), with the highly supplemented soy-pawpaw beverage having the lowest $\mathrm{pH}$ value (6.8). These results are in congruent with the findings of Njoya et al. (2017) who reported slight decrease in $\mathrm{pH}$ values $(5.01-4.99)$ of pawpaw enriched yoghurt. In contrary, Othman et al. (2019) reported increased in the $\mathrm{pH}$ values $(5.66-5.82)$ of pawpaw enriched plain yoghurt. Reduction in the $\mathrm{pH}$ values of the soy-pawpaw beverage with increasing supplementation level could be due to the presence of organic acids in ripe pawpaw fruit (Hernandez et al., 2009) and low pH (3.7 - 4.5) of pawpaw fruit (Frazier and Westhoff, 1995). However, the $\mathrm{pH}$ values $(7.1-6.8)$ of the soy-pawpaw beverages are higher than the $\mathrm{pH}$ values reported for fruits and vegetable juices (3 - 5) (Harris et al., 1991), cocktail juices $(4.82-4.99)$ (Adubofuor et al., 2010), orange juices $(3.23$ - 4.08) (Ndife et al., 2013) and cashew juice (4.1) (Emelike and Ebere, 2015). This suggests that the soy-pawpaw beverage will be well tolerated by juice consumers.

TSS contents in fruit juice are directly related to the sugar contents of the juice. Supplementation of soymilk with pawpaw puree significantly $p \leq 0.05$ increased the total soluble solids (TSS) of the beverages. Soy-pawpaw beverages with the highest supplementation level $(40 \%)$ had the highest TSS value $\left(8.5^{\circ} \mathrm{Brix}\right)$ among the enriched soymilk beverages, while the plain soymilk beverage had the least TSS value (5.5 ${ }^{\circ}$ Brix). Higher TSS values recorded for soy-pawpaw beverage compared to the plain soymilk could be due to high total sugar in pawpaw fruit. Total sugar contents of ripe pawpaw pulp are reported to be between $10.3 \%$ to $14.3 \%$, depending on the pawpaw variety (bello and Enidiok, 2017). Thus, high TSS values recorded for samples with higher supplementation level $(>20 \%)$ could be due to the enrichment of the soymilk with sweetness of ripe pawpaw.

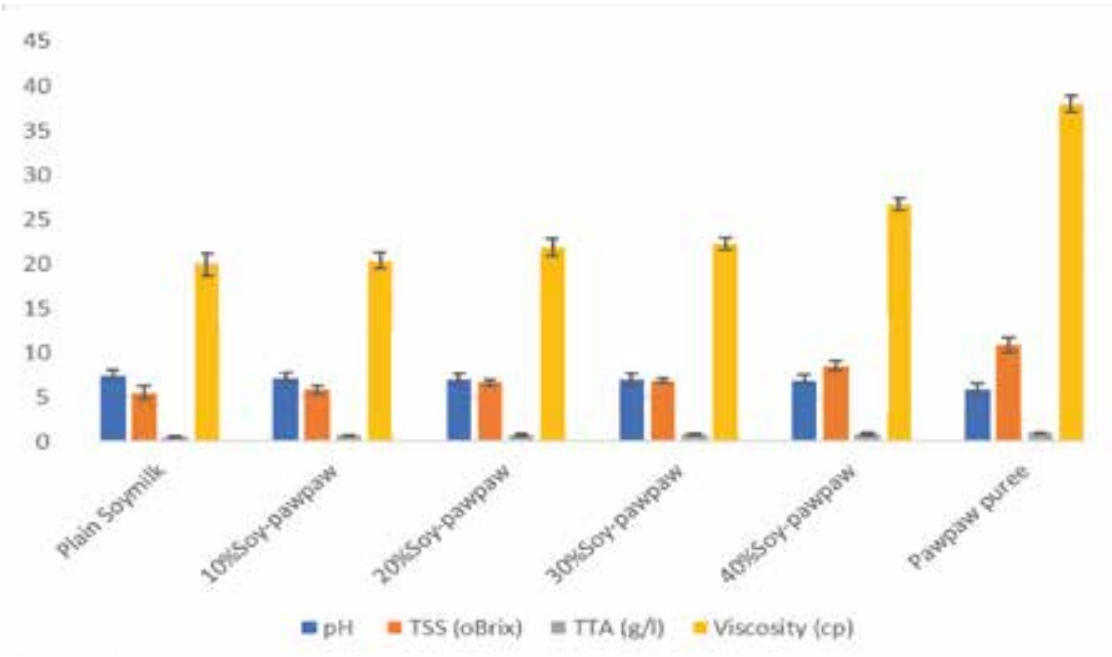

Fig. 1. Physicochemical properties of pawpaw enriched soymilk beverages 
This is an indication that the soy-pawpaw beverages will be sweeter than soymilk. The total soluble solid values (5.8 $8.5{ }^{\circ}$ Brix) recorded for soy-pawpaw beverage in this study are similar to the TSS values $\left(8.17-9.91{ }^{\circ}\right.$ Brix $)$ for soy-carrot flavoured with beetroot (Banigo et al., 2015) and within the range of TSS $(0.50-11.80 \%)$ reported for commercial orange juice samples (Ndife et al., 2013). The conformity of the TSS values of the soy-pawpaw beverages with commercially available juice samples indicates that the beverages will be generally acceptable in terms of taste.

Total titratable acidity (TTA) of the beverages increased with increasing supplementation with pawpaw puree in the soy-pawpawbeverages (Fig. 1). The TTA values of the enriched soymilk beverages increased from $0.53-0.87 \mathrm{~g} / \mathrm{l}$, with the $10 \%$ Soy-pawpaw beverages having TTA value significantly lower $(\mathrm{p} \leq 0.05)$ than that of $40 \%$ Soy-pawpaw beverage.The increments in the TTA of the soy-pawpaw beverages with increasing pawpaw puree supplementation with pawpaw puree could be due to the presence of numerous organic acids in pawpaw fruit. According to Hernandez et al. (2009), pawpaw fruit contains relatively high concentration of citric (335 mg/100 g FW) and malic acid (209 mg/100 g FW), in addition to low concentration of other fruit acids such as quinic acid, succinic acid, tartaric acid, oxalic acid, and fumaric acid. Although there was no significant difference $(\mathrm{p} \geq 0.05)$ in the TTA values of the soy-pawpaw beverages at $10-20 \%$ supplementation level, the TTA value of the $100 \%$ soymilk (control) sample was significantly different from those of the soy-pawpaw beverages. The relatively high TTA values of the soy-pawpaw beverages indicates that the samples may have better keeping quality than soymilk. This is because fruit acids dominant microflora in foods and determines the shelf stability of food products. Although acidic drinks are less susceptible to bacterial action, they may be prone to yeasts and moulds action.

The viscosity of the plain soymilk (19.9 cp) was significantly $(\mathrm{p} \leq 0.05)$ lower than those of the soy-pawpaw beverage samples $(20.3-26.7 \mathrm{cp}) .10 \%$ Soy-pawpaw beverage had the lowest viscosity value $(20.3 \mathrm{cp})$ while the $40 \%$ Soy-pawpaw drink had the highest viscosity $(26.7 \mathrm{cp})$. Higher viscosity recorded for the soy-pawpaw beverages, especially at higher supplementation levels could be due to high solid contents of pawpaw puree. High viscosity value of the soy-pawpaw beverages could also be attributed to relatively high fibre content $(6.2-11.2 \%)$ in pawpaw fruit (Chukwuka et al., 2013). Past study reported higher consumer preference for viscous soy beverages (Terhaag et al., 2013). This indicates that soy-pawpaw beverages produced from higher supplementation ratio $(>20 \%)$ will be acceptable by soymilk consumers.

Vitamin $A$ and $C$ contents of the pawpaw enriched soymilk beverage

The vitamin contents of the soy-pawpaw beverages are presented in Fig. 2. Vitamin A plays vital roles in the wellbeing and healthy livelihoods of people in general, and children, and pregnant women in particular. It is involved in immune function, vision, reproduction and cellular communication. Vitamin $\mathrm{C}$ on the other hand, is a powerful water-soluble antioxidant that helps to protect other naturally occurring antioxidants (IOM, 2000). Vitamin A and vitamin $\mathrm{C}$ contents of the soy-pawpaw beverages significantly

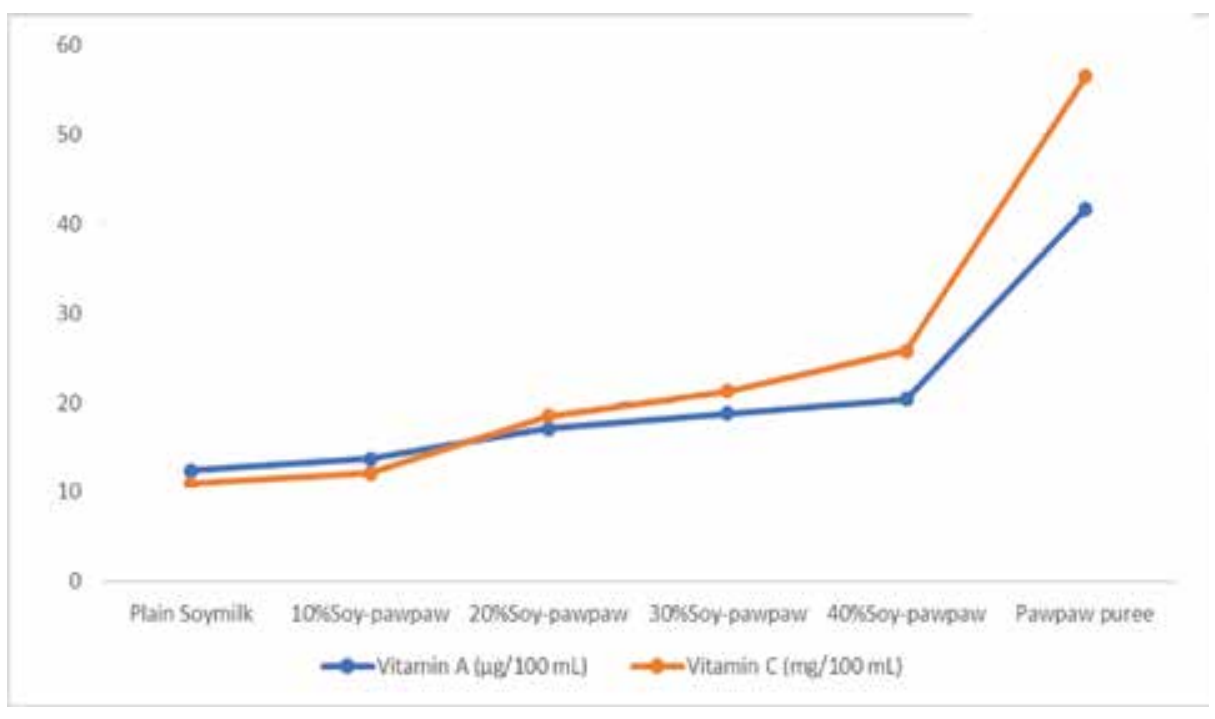

Fig. 2. Vitamin A and $C$ contents of pawpaw enriched soymilk beverage 
increased at $>10 \%$ pawpaw puree supplementation (Fig. 2). Vitamin A contents $(13.4-20.4 \mu \mathrm{g} / 100 \mathrm{ml})$ of the soy-pawpaw beverages were significantly $(\mathrm{p} \leq 0.05)$ higher than that of the plain soymilk $(12.4 \mu \mathrm{g} / 100 \mathrm{ml})$. Similarly, Vitamin C contents of the soy-pawpaw beverages increased with increasing supplementation level. 40\% soy-pawpaw beverage had the highest vitamin $\mathrm{C}$ content $(25.8 \mathrm{mg} / 100 \mathrm{ml})$ while 10\% soy-pawpaw beverage had the lowest Vitamin $\mathrm{C}$ content $(12.09 \mathrm{mg} / 100 \mathrm{ml})$. In general, vitamin $\mathrm{A}$ and $\mathrm{C}$ contents of the soy-pawpawbeverageswere higher than that of the plain soymilk (Fig. 2).

High values of vitamin A and $\mathrm{C}$ reported for the soy-pawpaw beverages could be due to high values of these vitamins in pawpaw fruit. According to USDA (2019a), vitamin A and C contents of pawpaw fruit is $45 \mu \mathrm{g} / 100 \mathrm{~g}$ and $60.9 \mathrm{mg} / 100 \mathrm{~g}$, respectively. Chukwuka et al. (2013), also reported fruits vitamin $\mathrm{A}$ and $\mathrm{C}$ values for ripe pawpaw fruit. However, vitamin C contents $(12.09-25.8 \mathrm{mg} / 100 \mathrm{ml})$ of the soy-pawpaw beverages reported in this study is lower than the vitamin $\mathrm{C}$ content (43 mg/100 g) of fermented soymilk drink (Zhao and Shah, 2014), but higher that the vitamin C contents $(9.53-9.82 \mathrm{mg} / 100 \mathrm{~g})$ of carrot fortified soymilk (Madukwe and Eme, 2012). The differences could be due to different pawpaw cultivars used in the studies, and differences in the processing methods employed in the studies. In addition, vitamin C contents $(12.09-25.8 \mathrm{mg} /$ $100 \mathrm{ml}$ ) of the pawpaw enriched soymilk is within the vitamin C contents (9.18 -32.06 mg/ $100 \mathrm{ml})$ of imported and local juices in Nigeria (Nwozo et al., 2017).
Vitamin A contents $(13.7-20.4 \mu \mathrm{g} / 100 \mathrm{ml})$ of the soy-pawpaw beverages are higher than vitamin A content (6 $\mu \mathrm{g} / 100 \mathrm{~g}$ ) of plain soymilk powder (Mazumder and Hongsprabhas, 2016). Similarly, the vitamin A contents of the soy-pawpaw beverages are higher than Vitamin A contents $(0.45-8.80 \mu \mathrm{g} / 100 \mathrm{ml})$ of commercial juices in Nigeria (Nwozo et al., 2017).

Although the vitamin $\mathrm{C}$ contents of the soy-pawpaw beverages $(12.09-25.8 \mathrm{mg} / 100 \mathrm{ml})$ were lower than the recommended dietary allowance (RDA) of vitamin $\mathrm{C}$ for men and women $(60 \mathrm{mg})$, and the amount of vitamin $\mathrm{C}(90-$ $100 \mathrm{mg}$ ) required for optimum reduction of chronic disease risk in non-smoking men and women (Carr and Frei, 1999), the enriched beverages can contribute to vitamin $C$ intake of consumers.

\section{Mineral composition of the pawpaw enriched soymilk}

Minerals are nutritionally important components in food, which are essential for healthy living. They are vital for normal growth, maintenance, effective immune system and prevention of cell damage (Kassa and Hailay, 2014). In addition, minerals are involved in growth and production of bones, teeth, hair, blood, nerves, skin, enzymes and hormones, blood circulation, cellular integrity, energy production and muscle contraction (Kassa and Hailay, 2014). The macro-mineral composition of the pawpaw enriched soymilk beverages is presented in Table II.

Table II. Mineral composition of pawpaw enriched soymilk beverage

\begin{tabular}{lccccc}
\hline Sample & $\mathrm{Ca}(\mathrm{mg} / 100 \mathrm{~mL})$ & $\mathrm{K}(\mathrm{mg} / 100 \mathrm{~mL})$ & $\mathrm{Mg}(\mathrm{mg} / 100 \mathrm{~mL})$ & $\mathrm{Na}(\mathrm{mg} / 100 \mathrm{~mL})$ & $\mathrm{P}(\mathrm{mg} / 100 \mathrm{~mL})$ \\
\hline Pawpaw puree & $21.10 \pm 0.01^{\mathrm{b}}$ & $183.45 \pm 0.05^{\mathrm{a}}$ & $94.63 \pm 0.14^{\mathrm{a}}$ & $7.65 \pm 0.04^{\mathrm{e}}$ & $25.01 \pm 0.61^{\mathrm{e}}$ \\
Plain soymilk & $102.38 \pm 0.02^{\mathrm{a}}$ & $120.13 \pm 0.03^{\mathrm{b}}$ & $54.74 \pm 0.07^{\mathrm{b}}$ & $34.00 \pm 0.02^{\mathrm{a}}$ & $50.65 \pm 1.18^{\mathrm{d}}$ \\
$10 \%$ Soy-pawpaw & $102.59 \pm 0.03^{\mathrm{a}}$ & $120.52 \pm 0.02^{\mathrm{b}}$ & $54.83 \pm 0.03^{\mathrm{b}}$ & $29.34 \pm 0.02^{\mathrm{b}}$ & $52.10 \pm 0.03^{\mathrm{d}}$ \\
20\%Soy-pawpaw & $103.06 \pm 0.24^{\mathrm{a}}$ & $121.73 \pm 0.29^{\mathrm{a}}$ & $56.01 \pm 0.04^{\mathrm{a}}$ & $25.72 \pm 0.25^{\mathrm{c}}$ & $60.74 \pm 0.05^{\mathrm{c}}$ \\
30\%Soy-pawpaw & $103.25 \pm 0.03^{\mathrm{a}}$ & $122.10 \pm 0.57^{\mathrm{a}}$ & $56.82 \pm 0.05^{\mathrm{a}}$ & $25.01 \pm 0.02^{\mathrm{c}}$ & $63.19 \pm 0.02^{\mathrm{b}}$ \\
40\%Soy-pawpaw & $103.88 \pm 0.04^{\mathrm{a}}$ & $122.50 \pm 0.03^{\mathrm{a}}$ & $57.11 \pm 1.19^{\mathrm{a}}$ & $20.97 \pm 0.14^{\mathrm{d}}$ & $65.60 \pm 0.03^{\mathrm{a}}$ \\
\hline
\end{tabular}

Values are mean \pm standard deviation $(\mathrm{n}=3)$. Values with different superscripts are significantly different $(\mathrm{P} \leq 0.05)$ 
The calcium content of the beverage did not increase significantly $(\mathrm{p} \geq 0.05)$ as the proportion of pawpaw puree increased in the beverage samples. This could be due to low concentration of calcium in pawpaw fruit. According to USDA (2019a), the calcium content of pawpaw fruit is $20 \mathrm{mg} / 100 \mathrm{~g}$. In contrary, Saxholt et al. (2008) reported higher values $(57.93-255.9 \mathrm{mg} / 100 \mathrm{~g})$ for calcium in ripe pawpaw fruit. This could be due to variety differences. However, the calcium contents $(102.59-103.88 \mathrm{mg} / 100$ $\mathrm{ml})$ of the pawpaw enriched beverages were higher than the calcium contents $(21.00-24.20 \mathrm{mg} / 100 \mathrm{~g})$ of pawpaw juice-milk blend (Adebayo-Oyetoro et al., 2016). This could be due to high calcium contents $(125 \mathrm{mg} / 100 \mathrm{~mL})$ in soymilk (USDA, 2019b).

The potassium content of the beverages ranged from 120.13 to $122.50 \mathrm{mg} / 100 \mathrm{ml}$ with the plain soymilk having the lowest potassium value while the soymilk beverage enriched with $40 \%$ pawpaw puree had the highest value. High potassium contents in the beverages could be due to high potassium contents in pawpaw fruit $(185 \mathrm{mg} / 100 \mathrm{~g})$ and soymilk (123 mg/100 ml) (USDA, 2019b). Similarly, Puwastien et al. (2000), reported high potassium contents $(1,234 \mathrm{mg} / 100 \mathrm{~g})$ for pawpaw fruit. The potassium contents of the pawpaw enriched soymilk are within the range of potassium contents $(152.5$ and $305 \mathrm{mg} / 100 \mathrm{ml})$ of fruit juices (Nwozo et al., 2017).

The magnesium contents $(54.74-57.11 \mathrm{mg} / 100 \mathrm{ml})$ of the beverage significantly $(\mathrm{p} \leq 0.05) \quad$ increased at higher enrichment levels (Table II). This could be due to high magnesium content $(95.24 \mathrm{mg} / 100 \mathrm{~g})$ in pawpaw fruit (Sanchez-Castillo et al., 1998). However, enrichment of soymilk with $10 \%$ pawpaw puree did not significantly ( $\mathrm{p} \geq$ 0.05 ) increase the magnesium content of the beverage. The magnesium contents of the enriched soymilk beverages are within the magnesium contents $(53.76-54.82 \mathrm{mg} / 100 \mathrm{~g})$ of soymilk produced from different improved soybeans varieties (Ugochi and Chukwuma, 2015).

The sodium contents of the beverages decreased (34.0 $20.97 \mathrm{mg} / 100 \mathrm{ml}$ ) with increasing enrichment ratio. Thus, enrichment of soymilk with pawpaw puree reduced significantly $(p \leq 0.05)$ the sodium contents of the beverages. This could be due to low sodium content $(8 \mathrm{mg} / 100 \mathrm{~g})$ in pawpaw fruit (USDA, 2019a). Highest sodium concentration $(34 \mathrm{mg} / 100 \mathrm{ml})$ was recorded for the plain soymilk beverage. This could be due to high sodium content $(50 \mathrm{mg} / 100 \mathrm{~g})$ in soymilk (USDA, 2019b). Lower sodium values (20.97 $29.34 \mathrm{mg} / 100 \mathrm{ml}$ ) recorded for the pawpaw enriched soymilk beverages indicate that the beverages will not contribute to high sodium intake.
The phosphorus contents $(52.1-65.6 \mathrm{mg} / 100 \mathrm{ml})$ of the enriched soymilk beverages containing $>10 \%$ pawpaw puree was significantly higher than that of the plain soymilk ( 50.65 $\mathrm{mg} / 100 \mathrm{ml}$ ). The phosphorus contents of the enriched soymilk beverages are however, lower than phosphorus values $(84.55-89.63 \mathrm{mg} / 100 \mathrm{~g})$ of soymilk produced from different improved soybeans (Ugochi and Chukwuma, 2015). This could be due to variety differences in the soybean's cultivar used for the soymilk production.

In general, high macro-mineral contents (calcium, potassium, magnesium and phosphorus) of the beverage indicates that the beverage will enhance the macro-mineral intake of consumers.

Sensory evaluation of the pawpaw enriched soymilk beverage

The results of the sensory evaluation of the pawpaw enriched soymilk beverages are shown in Fig. 3. Sensory attributes are important parameter that determines consumer's acceptability of new products. As shown in Fig. 3, the plain soymilk (control) sample was highly rated in terms of colour (7.2) compared to the colour $(6.0-6.6)$ of the soy-pawpaw beverages. Lower sensory rating recorded for the colour of the soy-pawpaw beverages compared to the plain soymilk drink could be due to familiarity of the panelists with the milky colour of plain soymilk beverage.

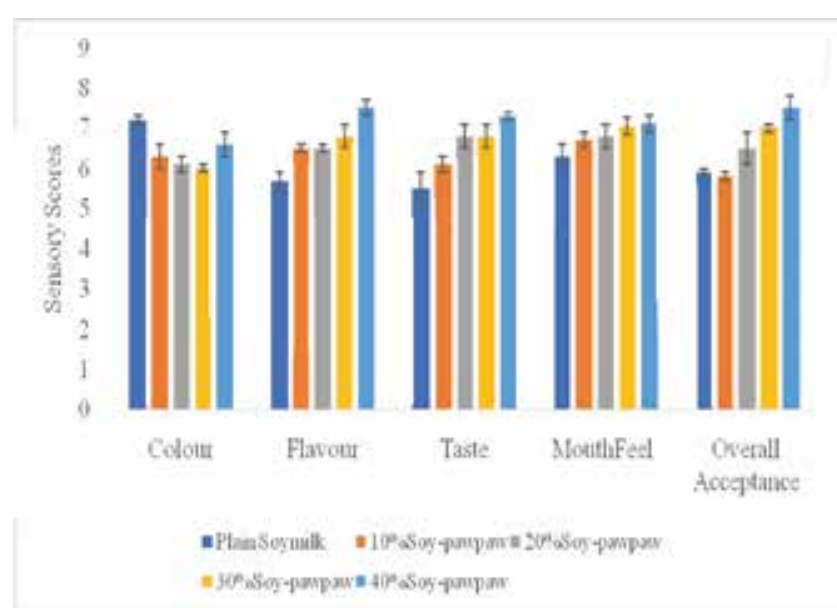

Fig. 3. Sensory evaluation results of the pawpaw enriched soymilk beverage

The flavour (6.5 - 7.5), taste (6.1 -7.3), and mouthfeel (6.7 7.1 ) of the soy-pawpaw beverages were highly rated by the panelists compared to the flavour (5.7), taste (5.5), and mouthfeel (6.3) of plain soymilk. Higher sensory rating for flavour of the soy-pawpaw beverage samples could possibly 
be because of the ability of the pawpaw puree (due to its fruity flavour) to mask the beany flavour of soybeans in the beverages. Higher sensory scores for taste of the soy-pawpaw drinks could be due to the sweet taste of the beverage as imparted by pawpaw puree sweetness. This result corroborates the TSS values of the pawpaw enriched soymilk beverage (Fig. 1). Higher sensory scores recorded for the beverage could be due to high viscosity of the pawpaw enriched beverage samples compared to plain soymilk (Fig. 1). According to Terhaag (2013), consumers have high preference for viscous soymilk beverages.

In terms of overall acceptance, soymilk sample enriched with $40 \%$ pawpaw puree had the highest sensory score (7.5) while plain soymilk had the least sensory score (5.9). Highest overall acceptance rating recorded for the $40 \%$ Soy- pawpaw drink could be due to the general high rating of the $40 \%$ pawpaw puree enriched soymilk beverage in terms of most of the sensory attributes. The acceptance rating of the soy-pawpaw beverages $(5.8-7.5)$ reported in this study is within the range of the acceptance value $(6.05-7.80)$ reported for fruits incorporated soy drink (Banigo et al. (2015).

\section{Conclusion}

The findings of this study have established that enrichment of soymilk beverage with pawpaw puree produced beverages with enhanced physicochemical properties and high concentration of vitamin $\mathrm{A}$ and $\mathrm{C}$, and minerals especially at $40 \%$ supplementation level. Soy-pawpaw beverage produced from $40 \%$ pawpaw puree had the highest sensory score rating for flavour, taste, mouthfeel and overall acceptance, but lower rating than plain soymilk in terms of colour. The soy-pawpaw beverage produced in this study will complement vitamin $\mathrm{A}$ and $\mathrm{C}$, and macro-mineral intake of consumers, and add variety to soymilk beverage. There is need for further studies on antioxidant properties, storage stability and development of optimum packaging materials for the soy-pawpaw beverages.

\section{References}

Adebayo-Tayo BC, Adegoke AA, and Akinjogunola OJ (2008), Microbial and physicochemical quality of powdered soymilk samples in Akwa Ibom, South Southern Nigeria, African J. Biotechnol. 8(13): 3066-3071.

Adebayo-Oyetoro AO, Ogundipe OO, Adeyemo IG, Ogundipe FO, Bamdele FA, and Adeyeye SAO
(2016), Chemical, sensory and shelf life study of pawpaw juice-milk blends, J Cogent Food Agric 2(1): 1-9. DOI: $10.1080 / 23311932.2016 .1271276$

Adeleke OE and Odelola HA (1997), Plasmid profiles of multiple drug resistance local strains of Staphylococcus species, African J. Sci. 7: 191221.

Adubofuor J, Amankwah EA, Arthur BS and Appiah F (2010), Comparative study related to physico-chemical properties and sensory qualities of tomato juiceand cocktail juice produced from oranges, tomatoes and carrots,African J. Sci. $\quad$ 4(7): $\quad 427-433 . \quad$ DOI: 10.5897/AJFS.9000058

Aka S, Camara F, Nanga YZ, Ukou YG, and Dje KM (2008), Evaluation of organic acids and sugars contents during the production of tchapalo, a traditional sorghum beer in Côte d'Ivoire,J. Food Technol.6(5): 189-195.

AOAC (2012), Official method of analysis, 19 $19^{\text {th }}$ Ed. Association of Official Analytical Chemist, Washington.

Awolu OO, Aderinola TA and Adebayo IA (2013), Physicochemical and rheological behavior of African Star apple (Chrysophyllum albidium) juice as affected by concentration and temperature variation, J. Food Process. Technol.4: 229-240. DOI: 10.4172/2157-7110.1000229.

Bolarinwa IF, Aruna TE, Adejuyitan JA, Adeyemo GA and Alabi OD, (2020a), Chemical, physical and sensory properties of pawpaw fortified pan bread, J. Food Chem. Nanotechnol. 6(2): $65-71$. DOI: 10.17756/jfcn.2020-085

Bolarinwa IF, Aruna TE, Abioye $\mathrm{AO}$ and Adelakun $\mathrm{OE}(2020 \mathrm{~b})$, Influence of cashew steaming on the quality attributes of cashew-pawpaw mixed fruit juice, Agr osearch 20(1): 34-44. DOI: 10.4314/ agrosh.v20i1.4S

Banigo EB, Kiin-Kabari DB and Owuno F(2015), Physicochemical and sensory evaluation of soy/carrot drinks flavoured with beetroot, African J. Food Sci. Technol. 6(5): 136-140.

Bello FA and Enidiok SE (2017), Effect of postharvest ripening stages on the nutritional compositions of pawpaw (Carica papaya)varieties, Nigerian J. Agric. Food Environ. 13(2): 86-89. 
Carr AC and Frei B (1999), Toward a new recommended dietary allowance for vitamin $\mathrm{C}$ based on antioxidant and health effects in humans,Am. J. Clin. Nutr. 69:1086-107. DOI: 10.1093/ajcn/69.6.1086

Chukwuka KS, Iwuagwu M and UkaUN (2013), Evaluation of nutritional components of Carica papaya L. at different stages of ripening,IOSR J. Pharm. Bio. Sci. (IOSR-JPBS) 26(4): 13 - 16.

Dimitrovski D, Bicanic D and Lutarotti S(2010), The concentration of trans-lycopene in postharvest watermelon; An evaluation of analytical data obtained by direct methods, J. Postharvest Bio. Technol. 58(1): 21-28. DOI: $10.1016 /$ j.postharvbio.2010.05.002

Emelike NJT and Ebere CO(2015), Effect of packaging materials, storage conditions on the vitamin $\mathrm{C}$ and $\mathrm{pH}$ value of cashew-apple (Anacardium occidentale L.) juice, J. Food Nutr. Sci.3(4): 160-165. DOI: 10.11648/j.jfns.20150304.14

Frazier WC and Westhoff DC (1995), Food Microbiology, $4^{\text {th }}$ Ed., McGraw Hill, New Delhi.

Harris A, Key J and Silcocks B(1991), Dietary Carotene, $3^{\text {rd }}$ Ed. Prenticehall Press, New York.

Hernandez Y, Lobo MG and Gonzalez M (2009), Factors affecting sample extraction in the liquid chromatographic determination of organic acids in papayaand pineapple, Food Chem. 114: 734-741. DOI: 10.1016/j.foodchem.2008.10.021

IOM (2000), Ascorbic Acid In: Dietary reference intakes for ascorbic acid, vitamin E, selenium and carotenoids, National Academy Press, Washington.

Iwe MO (2003), The science and technology of soybean, $J$. Sci. Food Agric. 4(4): 79-145.

Jiang FJ, Lv JQ and Tai A (2000), Bioactive components of soybeans and their functions, Soybean Sci. 19: 160-164.

Kassa B and Hailay K (2014), Determination of trace metals $(\mathrm{Mn}, \mathrm{Cu} \& \mathrm{Ni})$ content in Moringa Oliefera using atomic absorption spectroscopy, Journal of Biology, Agriculture and Healthcare, 4(17): $52-55$.
Kolapo AL and Oladimeji GR (2008), Production and quality evaluation of soy-corn milk, J. Appl. Biosci. 1(2): 4-17.

Madukwe E and Eme PE (2012), Chemical evaluation and sensory attributes of soymilk fortified with carrot powder, African Journal of Food Science, 6(20): 483-486.

Mazumder MAR and Hongsprabhas P (2016), A review on nutrient quality of soymilk powder for malnourished population,Pakistan J. Nutr. 15(6): 600-606.

McWatters KH, Resurreccion LR, Beuchat $\mathrm{H}$ and Phillips R (1995), Use of soybean and cowpea in wheat-based products containing composite flours, Plant Foods Hum. Nutr. 47: 71-87. DOI: 10.1007/BF01088169

Ndife J, Awogbenja D and Zakari U (2013), Comparative evaluation of the nutritional and sensory quality of different brands of orange-juice in Nigerian market, African J. Food Sci. 7(12): 479-484. DOI: 10.5897/AJFS2013.1060

Njoya MA, Nain CW, Mahbou PY, Mendi SD and Imele H (2017), Physicochemical and sensory properties of pawpaw (Carica papaya Linn) flavoured yoghurt, Afri. J. Food Agric. Nutr. Dev. 17(3): 12311-12342. DOI: $10.18697 /$ ajfand.79.15785

Nwachukwu E, Achi OK and Ijeoma IO (2010), Lactic acid bacteria in fermentation of cereals for the production of indigenous Nigerian foods, African J. Food Sci. Technol. 1(2): 021-026.

Nwozo SO, Aladesuru OO, and Hammed WA (2017), Evaluation of the proximate, mineral and vitamin content of juices produced from imported and local lesser known fruits in Nigeria, Annals. Food Science and Technology 18(3): 402- 412.

Okwu DE and Josiah C(2006), Evaluation of the chemical composition of two Nigerian medicinal plants,African J. Biotechnol. 5(4): $357-361$.

Othman N, Hazren AH and Suleiman N(2019),Physicochemical properties and sensory evaluation of yogurt nutritionally enriched with papaya,Food Res. 3(6): 791-797. DOI: 10.26656/fr.2017.3(6).199

Puwastien P, Burlingame B, Raroengwichit M and Sungpuag P (2000), ASEAN Food CompositionTables of Nutrition, Mahidol University, Thailand. 
Sanchez-Castillo CP, Dewey PJS and Aguirre A (1998), The Mineral Content of Mexican Fruits and Vegetables, $J$. Food Compos. Anal.11: 340-356.

Saxholt E, Christensen AT, MØller A, Hartkopp HB, Hess YK, and Hels OH (2008), Danish Food Composition Databank, revision 7, Department of Nutrition, National Food Institute, Technical University of Denmark, http://www.foodcomp.dk/

Singh E, Kalyani B, Reddy BS, Kalyani PU, Devi H, Ravi L and Shanti M (2015), Study on dehydration of papaya slices using osmotic dehydration mediated hot air oven drying, IOSR J. Environ. Sci. Toxicol. Food Technol. 9(11): 72-95. DOI: 10.9790/2402-091127295

Terhaag MM, Almeida MB and Benassi MDe-T (2013), Soymilk plain beverages: correlation between acceptability and physical and chemical characteristics, Food Sci. Technol. Campinas. 33(2): 387-394. DOI: 10.1590/S0101-20612013005000052
Ugochi NF and Chukwuma UM (2015), Nutrient and sensory quality of soymilk produced from different improved varieties of soybean, Pakistan Journal of Nutrition 14 (12): 898-906.

USDA (2019a), United States Department of Agriculture, National Nutrient Database for Standard Reference.https://fdc.nal.usda.gov/fdc-app.html\#/food -details/169926/nutrients

USDA (2019b), United States Department of Agriculture, National Nutrient Database for Standard Reference. https://fdc.nal.usda.gov/fdc-app.html\#/food-details/ 456844/nutrients

Zhao D and Shah NP (2014), Changes in antioxidant capacity, isoflavone profile, phenolic and vitamin contents in soymilk during fermentation,LWT - Food Sci. Technol.5 8(2): 454 - 462. DOI: 10.1016/j.lwt.2014.03.029 